\title{
Experimental Results Airotech Fuels and Brookville Coal CRADA 92-003, Final Report
}

July 21, 1992

Henry W. Pennline

Mark Freeman

U.S. Department of Energy

Pittsburgh Energy Technology Center

626 Cochrans Mills Road

Pittsburgh, PA 15236

and

Airotech, Inc.

Boyle Center

120 East 9th Avenue

Homestead, PA 15120

Emmisumon or nma ocoun '

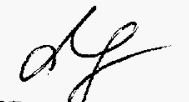




\section{Disclaimer}

This report was prepared as an account of work sponsored by an agency of the United States Government. Neither the United States Government nor any agency thereof, nor any of their employees, makes any warranty, express or implied, or assumes any legal liability or responsibility for the accuracy, completeness, or usefulness of any information, apparatus, product, or process disclosed, or represents that its use would not infringe privately owned rights. Reference herein to any specific commercial product, process, or service by trade name, trademark, manufacturer, or otherwise does not necessarily constitute or imply its endorsement, recommendation, or favoring by the United States Government or any agency thereof. The views and opinions of authors expressed herein do not necessarily state or reflect those of the United States Government or any agency thereof. 


\section{DISCLAIMER}

Portions of this document may be illegible electronic image products. Images are produced from the best available original document. 


\section{Experimental Results Airotech Fuels and Brookville Coal CRADA 92-003, Final Report}

July 21, 1992

Henry W. Pennline

Mark Freeman

U.S. Department of Energy

Pittsburgh Energy Technology Center

626 Cochrans Mills Road

Pittsburgh, PA 15236

and

Airotech, Inc.

Boyle Center

120 East 9th Avenue

Homestead, PA 15120 
Airotech, Inc.

PC92-003

$7 / 20 / 92$

\section{EXPERIMENTAL RESULTS - AIROTECH FUELS AND BROOKVILLE COAL}

\section{RESEARCH FACILITIES}

Residential Warm-Air Furnace

A decision was made to conduct screenings with actual stoker furnaces rather than building a batch or semi-continuous simulator furnace. To minimize coal/sorbent fuel fabrication costs, underfeed stoker units were selected based on their commercial availability at low thermal inputs. It was felt that the most important combustion/emissions experimental results would be transferrable to the travelling-grate and spreader stokers more commonly found in large commercial/industrial boilers. This assumption was based on the bulk of the existing stoker literature.

Central to this research is a typical $225,000 \mathrm{Btu} / \mathrm{hr}$ (thermal input) residential warm-air furnace (WAF) equipped with an underfeed stoker which normally delivers $16 \mathrm{lb} / \mathrm{hr}$ of coal solids with two additional speeds at 12 and $20 \mathrm{lb} / \mathrm{hr}$. At a typical residential furnace back pressure of 0.1 in $\mathrm{H}_{2} \mathrm{O}$, $1100 \mathrm{scfm}$ of hot air in the $150-225^{\circ} \mathrm{F}$ range can be produced depending upon the air intake temperature and furnace firing rate. The furnace/underfeed stoker was manufactured by the WillBurt Company. A cross-sectional diagram of the commercially-available system is presented in Figure 1. The WAF test facility has had a two-fold purpose: first, to establish a residential emissions data base under continuous, cyclic, and hold-fire operations; and second, to serve as a screening furnace for limited quantities of reconstituted coal fuels. On the latter issue, the WAF requires about $120 \mathrm{lb}$ of fuel per test day. The WAF furnace was modified and heavily instrumented in order to provide research quality measurements while operating the furnace in a realistic manner.

Before detailing the various system modifications, it is useful to summarize the basic principles of residential stoker operation. In typical off-the-shelf underfeed stoker designs, air flow is regulated by the arrangement of several dampers in key locations to ensure satisfactory combustion air flow based upon fuel bed resistance. Coal is conveyed through a screw tube and up into the inner hollow pit (retort) whereby it undergoes increasingly severe changes beginning with devolatilization and ending with combustion, characterized by a yellow-orange flame. Combustion air enters the retort about $1 / 3$ down from its brim through several rows of small air holes known as tuyeres. The key characteristic of the underfeed is its ever-changing, irregular fuel bed as coke constantly forms, falls, and burns. This behavior is dependent on stoker design, operating conditions, fuel particle size, and most importantly, fuel type. In general, the highest portions of the fuel bed can be one foot above the top of the retort. The combustion air is mechanically linked to the stoker motor to accommodate both the coal feed and burning rate; thus, as the fuel bed resistance increases, the combustion air back pressure increases. This causes the damper to open more, thereby allowing more combustion air to burn off the excess inventory. Overfire air occurs with air leakage through small slats in the firebox door. Typical recommended draft for these systems is $0.03-0.06$ in of $\mathrm{H}_{2} \mathrm{O}$ [1]. Unfortunately, the delicate balance of gas pressure variation does not permit the inclusion of additional flow resistances, including metering. 
To provide flow metering capability, the built-in combustion air blower was replaced with a more powerful blower to permit installation of a venturi and pneumatically-controlled butterfly valve. Similarly, an induced draft fan on the stack permits flue gas flow metering (orifice) and control (pneumatic valve). A calibrated rotary meter was used to standardize the orifice and venturi meters to ensure consistent flow monitoring. With the modified systems, draft and overfire air flow control is extremely consistent even under cyclic (combustion air on/off) operation which characterizes residential heating. Figure 2 presents an overall flow schematic of the WAF test facility.

Other modifications included the installation of a 1) variable-speed motor to improve fuel firing consistency and minimize the effects of fuel density variability on auger feed rates, 2) nitrogen purge line to the firebox in order to quench the fire at the end of testing, and 3) a sight port for visual observations, video recording, and dual-color pyrometer measurements of the firebox during testing.

\section{Analvtical Instrumentation}

The WAF is well instrumented in gas analyzer monitoring. Beckman Model 865 nondispersive infrared analyzers were used to track carbon dioxide (0-20\%) and carbon monoxide (0-5000 ppm) continuously. A Beckman Model 880 analyzer provided additional CO measurement in the 0-500 ppm range. This arrangement allows accurate, continuous monitoring of $\mathrm{CO}$ without changing analyzer ranges during WAF operations. Similarly, two total hydrocarbon (THC) analyzers were employed during tests. A Beckman Model $400 \mathrm{~A}$ is employed at the $0-10 \mathrm{ppm}$ range during continuous tests while a Beckman Model 400 analyzer provided coverage at $0-100 \mathrm{ppm}$. A Thermo Electron Model 10 chemiluminescent analyzer was used to track $\mathrm{NO}_{\mathrm{x}}$ emissions at the $0-1000 \mathrm{ppm}$ range while a Beckman Model $755 \mathrm{~A}$ paramagnetic oxygen analyzer was employed at the $0-25 \%$ level. Sulfur dioxide measurements were accomplished with two Horiba PIR-2000 (0-1000 ppm and $0-5000 \mathrm{ppm})$ and a moisture-compensated Horiba VIA-200 (0-200 ppm) nondispersive infrared analyzers.

The WAF gas sample was conditioned prior to analyzer measurement by continuously withdrawing the sample through a Mott Metallurgical 2-in diameter cylindrical, sintered stainless steel filter of 5 micron pore size for removal of particulates. To remove moisture, the sample passes through coiled tubing submerged in a $32^{\circ} \mathrm{F}$ ice bath prior to flue gas analysis. Vapor-liquid equilibrium calculations $\left(\mathrm{SO}_{2} / \mathrm{H}_{2} \mathrm{O}\right)$ and ion chromatography measurements of the condensate revealed an acceptably low removal of $\mathrm{SO}_{2}$ during moisture knockout. However, because of the inherent large interference between $\mathrm{H}_{2} \mathrm{O}$ and $\mathrm{SO}_{2}$ with $\mathrm{IR}$ absorption, a Perma Pure drier was installed to remove residual sample moisture from the ice bath-conditioned stream prior to the $\mathrm{SO}_{2}$ analyzers. Otherwise, a $32^{\circ} \mathrm{F}$ dewpoint could produce an interference of about $6 \mathrm{ppm} \mathrm{SO} \mathrm{SO}_{2}$ based on the typically accepted interference ratio $\left(100\right.$ ppm $\mathrm{H}_{2} \mathrm{O}=1$ ppm $\mathrm{SO}_{2}$ ) with infrared $\mathrm{SO}_{2}$ analyzers.

Data acquisition is centralized with a Kaye Corporation data logger which transmits pertinent values to a Digital Equipment Corporation PDP $11 / 70$ for data storage and operations display every 24 seconds. Fortran programs calculate the relevant engineering quantities -- for example, $\mathrm{lb} / \mathrm{hr}$ 
of $\mathrm{SO}_{2}, \mathrm{Btu} / \mathrm{hr}$ of flue gas sensible heat, etc. -- which are integrated over the length of the test to provide absolute quantities for material and energy balances.

\section{Combustion/Emissions Screening Procedure}

Screening tests are conducted in the WAF under continuous firing based on the desire to mimic the conditions found in large commercial and industrial boilers. Typically, a 1-hr feedscrew test was performed to reveal fuel grindability and determine auger feed (rpm) settings needed to achieve an approximate constant firing rate of $150,000 \mathrm{Btu} / \mathrm{hr}$ (input). Feedscrew tests also reveal the degree of fuel degradation which is an important consideration in comparing novel coal-based fuels with stoker coals.

After the feedscrew test, fresh fuel $(2-4 \mathrm{lb})$ and wood kindling were placed over the retort. After lighting, combustion air was initiated for 10-15 minutes to establish the fire before initiation of coal feed. Typically, a warmup period was conducted to establish the proper amount of combustion and overfire air. Initial conditions were set at $50 \%$ excess combustion air plus an additional $50 \mathrm{lb} / \mathrm{hr}$ of overfire air and then altered, if necessary, to achieve more optimum combustion for the subsequent formal 6-hour test period. During this period, air flows were generally constant and only occasional adjustments were made to ensure a good test burn. Bed temperatures were obtained with a Capintec Instruments, Inc. Ratio-Scope Model III dual-wavelength infrared pyrometer.

At the end of each test, combustion air and fuel feed were turned off; the firebox was allowed to cool for 10 minutes before flooding with nitrogen to extinguish the fire. The firebox ash was then partitioned into three categories according to its stage of combustion - powder ash, gray ash, and black ash/coke - to more carefully scrutinize combustion results. Powder ash consisted of the most well-burned, finely divided $(-1 / 4$ in) material relative to the other two fractions. Gray ash consists of larger pieces (plus $1 / 4$ in) while black ash/coke results from the least combustion. The partitioned ash samples are then separately weighed, crushed, riffled, and analyzed.

\section{COMBUSTION/EMISSIONS SCREENING RESULTS}

Table 1 presents the chemical analyses for Fuel $A$ and the Brookville coal used in the study. As the chemical analyses for Fuel B and the blended coal/paper fuels (Fuel A/Brookville, Fuel $\mathrm{B} /$ Brookville) are still pending, estimates are provided (where possible) in Table 1 based on the level of reported mixture proportions of paper extrudates, sodium bicarbonate and coal.

In viewing Table 1 , it is critical to realize that the analytical methods have been developed to assist in the characterization of coal types. This is particularly important in the volatile, fixed carbon, ash softening temperature, oxygen, and nitrogen determinations as it relates to the "reported" paper extrudate (Fuel A) values and estimates of the paper extrudate, sodium bicarbonate, and coal blended fuels. Various supplemental analytical measurements (e.g., char heating value, elements of ash) will need to be performed in this respect. 
One item of note concerns the fuel nitrogen content of the paper fuel. The most widely-accepted ASTM method (Kjeldahl nitrogen, a digestion technique) revealed an absence of nitrogen while the Leco nitrogen (a combustion technique) revealed considerable amounts as reported in Table 1. This suggests that nitrogen may be present in alternative forms (e.g., nitrates) within the paper fuel. Additional tests (e.g., ion chromatography) may be helpful here. The fuel nitrogen issue is curious in that while the paper fuels did exhibit very low $\mathrm{NO}_{\mathrm{x}}$ (see Table 2), the $\mathrm{NO}_{\mathrm{x}}$ was certainly measurable. In stoker literature, $\mathrm{NO}_{\mathrm{x}}$ formation is almost exclusively ascribed to fuel nitrogen pathways because the furnace temperatures are not typically high enough to generate thermal $\mathrm{NO}_{\boldsymbol{x}}$. Generally, only $5-15 \%$ of the fuel nitrogen is thought to be converted to $\mathrm{NO}_{\mathrm{x}}$.

Of considerable interest is the favorably low apparent sulfur level $(0.13 \mathrm{wt} \%$ sulfur, $0.32 \mathrm{lb}$ $\mathrm{SO}_{2}$ /MMBTU equivalent). It is significant to note the highly stringent ASTM laboratory error tolerance of \pm 0.05 absolute wt $\%$ sulfur is actually relatively high in this instance. For this reason, the WAF emissions results (discussed later) are probably more accurate in light of the high sensitivity $( \pm 2 \mathrm{ppm})$ of the low range $\mathrm{SO}_{2}$ analyzer.

Table 2 summarizes the most pertinent combustion and emissions results during the screening tests performed in the residential warm-air furnace (WAF). In comparing $\mathrm{SO}_{2}$ emissions, there are several inconsistencies which need to be resolved from further chemical analysis of the feedstocks and ash samples before any firm conclusions can be drawn.

Because of the lower density and heating value of the paper fuels (Fuel A and B), testing was conducted at about $120,000 \mathrm{Btu} / \mathrm{hr}$ rather than the $150,000 \mathrm{Btu} / \mathrm{hr}$ which had been used previously to characterize U.S. stoker coals and novel reconstituted coal-based fuels. The $120,000 \mathrm{Btu} / \mathrm{hr}$ firing rate was the maximum achievable in the WAF based on the present gear ratio design and motor rpm range.

The feedscrew tests of Fuel A and Fuel B yielded very favorable results with respect to size degradation, producing very little $(<10 \%$ less $1 / 4$ inch estimate) fines. No difficulties were encountered with the coal/paper blended fuels. Size distribution analyses on the feedscrew samples are pending. It is expected that the results will be very comparable to those observed previously with various U.S. stoker coals.

In conducting the combustion/emissions screening tests on Fuel A and B, more combustion air was required (93-107\% excess) relative to the Brookville coal and blended coal/paper fuels (33-51\% excess). As expected, the paper fuels do not exhibit swelling (caking) tendencies which is very favorable from a stoker operations view. The paper fuels did have an unusual tendency to produce a large fused ash plug within the retort. These ash plugs obstructs the flow of combustion air away from the fuel bed, which consequently necessitated more combustion air flow. As a result, the burning rate and emissions of $\mathrm{CO}$ and THC vary considerably during a test, despite the fact that the overall burnout (carbon conversion) is quite good. For this reason, the average $\mathrm{CO}$ and THC emissions are considerable for Fuel A and Fuel B as shown in Table 2. It is difficult to assess whether these tendencies would be as prevalent at a higher firing rate. It is likely, however, that these problems would not be as significant on a larger stoker equipped with an automatic ash removal system. 
No problems were encountered in the blended paper/Brookville tests. Burn rates and emissions were very steady once test conditions were established. The fuel bed was regular (based on previous experience), and illustrative of intensive combustion and radiant heat transfer.

\section{DISCLAIMER}

Reference in this paper to any specific commercial product, process, or service is to facilitate understanding and does not imply endorsement or favoring by the United States Department of Energy.

\section{REFERENCES}

[1] Instructions for the Care and Operation of Your Stoker, The Will-Burt Company. 


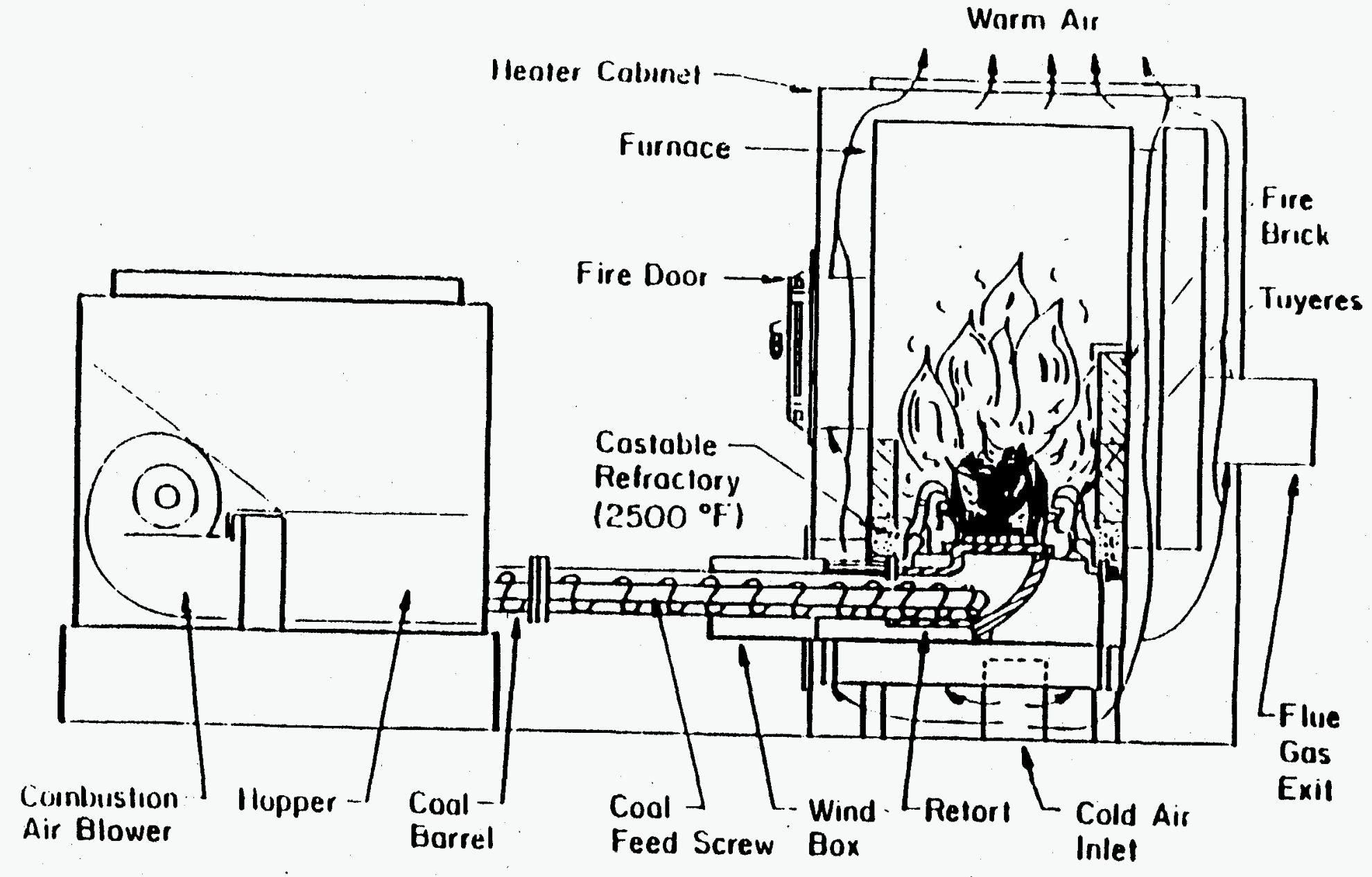

Figure 1 : Cross-Seclional View of Typical Residential Warm-Air Furnace 


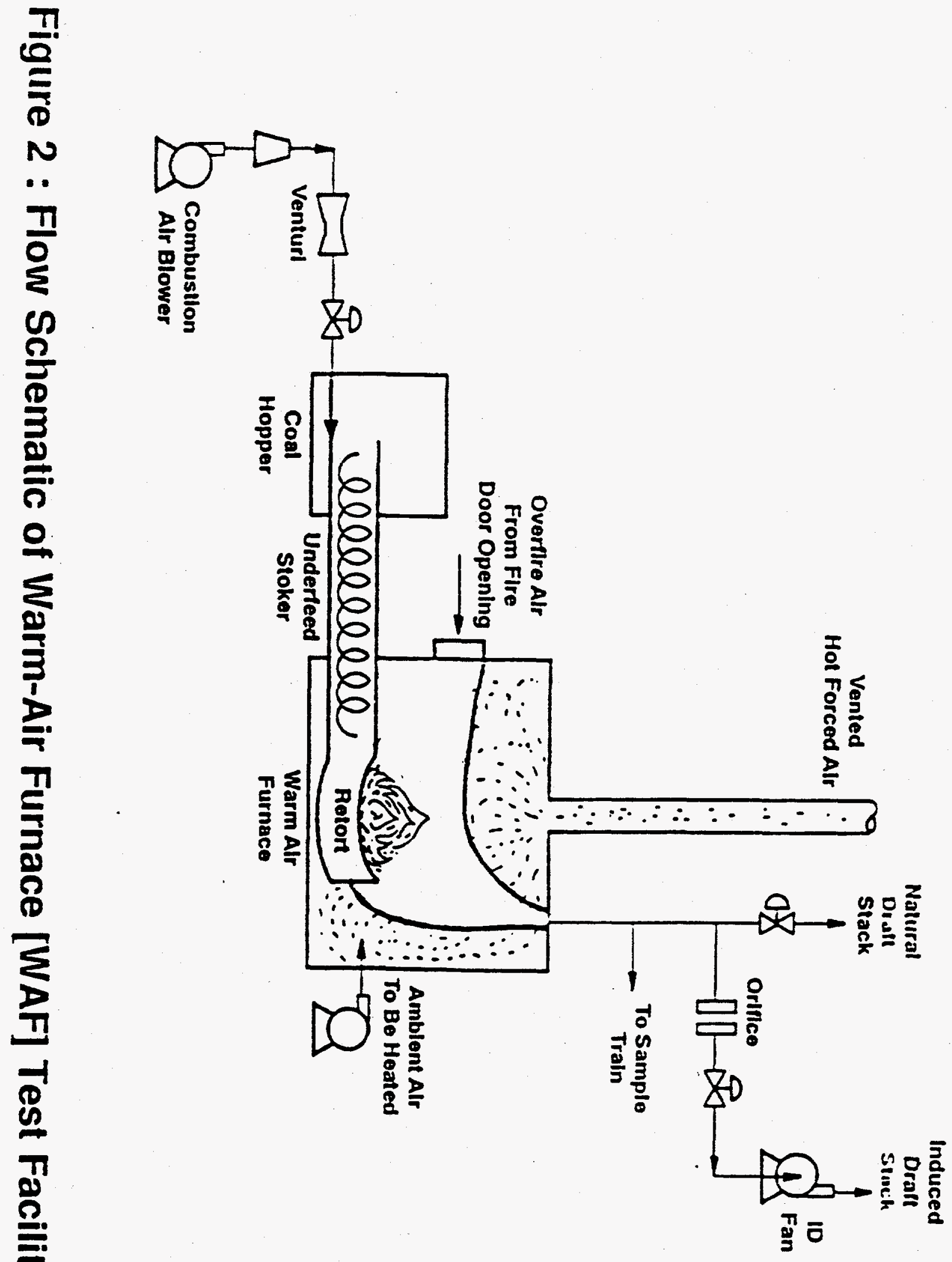


Table 1: Airotech Fuel and Brookville Coal Analyses

\begin{tabular}{|c|c|c|c|c|c|}
\hline Proximate (\%) & & Fuel $B$ & $A+B r k v l$ & $B+B r k v l$ & Brkvl \\
\hline $\begin{array}{l}\text { Moisture } \\
\text { Volatile Matter } \\
\text { Fixed Carbon } \\
\text { Ash }\end{array}$ & $\begin{array}{r}9.66 \\
69.53 \\
17.53 \\
3.28\end{array}$ & $\begin{array}{r}9.18 \mathrm{e} \\
68.67 \mathrm{e} \\
16.65 \mathrm{e} \\
5.50 \mathrm{e}\end{array}$ & $\begin{array}{r}6.86 \mathrm{e} \\
51.18 \mathrm{e} \\
37.21 \mathrm{e} \\
5.75 \mathrm{e}\end{array}$ & $\begin{array}{r}5.63 \mathrm{e} \\
50.77 \mathrm{e} \\
36.79 \mathrm{e} \\
6.81 \mathrm{e}\end{array}$ & $\begin{array}{r}2.40 \\
34.50 \\
55.10 \\
8.00\end{array}$ \\
\hline $\begin{array}{l}\text { Ultimate (\% dry) } \\
\text { Hydrogen } \\
\text { Carbon } \\
\text { Nitrogen } \\
\text { Sulfur } \\
\text { Oxygen } \\
\text { Ash }\end{array}$ & $\begin{array}{r}5.96 \\
48.29 \\
2.09 \\
0.13 \\
39.90 \\
3.63\end{array}$ & $\begin{array}{r}5.69 \mathrm{e} \\
46.41 \mathrm{e} \\
1.97 \mathrm{e} \\
0.13 \mathrm{e} \\
37.70 \mathrm{e} \\
6.05 \mathrm{e}\end{array}$ & $\begin{array}{r}5.42 \mathrm{e} \\
63.31 \mathrm{e} \\
1.77 \mathrm{e} \\
0.60 \mathrm{e} \\
22.80 \mathrm{e} \\
6.11 \mathrm{e}\end{array}$ & $\begin{array}{r}5.30 \mathrm{e} \\
62.41 \mathrm{e} \\
1.72 \mathrm{e} \\
0.60 \mathrm{e} \\
21.84 \mathrm{e} \\
7.21 \mathrm{e}\end{array}$ & $\begin{array}{r}4.96 \\
75.94 \\
1.50 \\
1.00 \\
8.42 \\
8.19\end{array}$ \\
\hline HHV (Btu/lb AR) & 7403 & $7001 \mathrm{e}$ & $10374 \mathrm{e}$ & $10182 \mathrm{e}$ & 13075 \\
\hline FSI & 0.0 & 0.0 & NA & NA & 3.0 \\
\hline $\begin{array}{l}\left.\text { AST Profile ( }{ }^{\circ} F\right) \\
\text { Initial } \\
\text { Softening } \\
\text { Hemi } \\
\text { Fluid }\end{array}$ & $\begin{array}{l}2062 \\
2248 \\
2269 \\
2274\end{array}$ & $\begin{array}{l}\text { NA } \\
\text { NA } \\
\text { NA } \\
\text { NA }\end{array}$ & $\begin{array}{l}\text { NA } \\
\text { NA } \\
\text { NA } \\
\text { NA }\end{array}$ & $\begin{array}{l}\text { NA } \\
\text { NA } \\
\text { NA } \\
\text { NA }\end{array}$ & $\begin{array}{l}2151 \\
2397 \\
2438 \\
2530\end{array}$ \\
\hline $\begin{array}{l}\text { Lb/MMBtu (max) } \\
\mathrm{SO}_{2}(f)\end{array}$ & 0.32 & $0.32 \mathrm{e}$ & $1.10 \mathrm{e}$ & $1.10 \mathrm{e}$ & 1.50 \\
\hline
\end{tabular}

Table note (e) denotes an estimate based on the reported percentages of paper extrudates, sodium bicarbonate, and coal. Experimental values are unavailable at this time. Since the ash softening temperature profile cannot be precisely predicted from the mixture components, a (NA) note is given in the table.

Table note (f) assumes that all sulfur is converted to $\mathrm{SO}_{2}$. 
Table 2 : WAF Screening Results Airotech Fuels and Brookville Coal

\begin{tabular}{|c|c|c|c|c|c|}
\hline FUEL TYPE & BRKVL & FUELA & FUELB & $\begin{array}{l}\text { BRKVL } \\
\text { FUELA }\end{array}$ & $\begin{array}{l}\text { BRKVL } \\
\text { FUELB }\end{array}$ \\
\hline $\begin{array}{l}\text { FUEL FEED RATE (LB/HR) } \\
\text { FIRING RATE IN } 1000 \text { BTU/HR }\end{array}$ & $\begin{array}{r}12.25 \\
160\end{array}$ & $\begin{array}{r}16.32 \\
121\end{array}$ & $\begin{array}{r}17.48 \\
122 \\
\end{array}$ & $\begin{array}{r}14.90 \\
154\end{array}$ & $\begin{array}{r}16.13 \\
163\end{array}$ \\
\hline $\begin{array}{l}\text { COMBUSTION AIR (LB/HR) } \\
\text { OVERFIRE AIR (LB/HR) } \\
\text { TOTAL AIR (LB/HR) }\end{array}$ & $\begin{array}{r}174 \\
57 \\
231\end{array}$ & $\begin{array}{r}182 \\
63 \\
245\end{array}$ & $\begin{array}{r}174 \\
78 \\
252\end{array}$ & $\begin{array}{r}175 \\
69 \\
244\end{array}$ & $\begin{array}{r}165 \\
78 \\
243\end{array}$ \\
\hline $\begin{array}{l}\% \text { EXCESS COMBUSTION AIR } \\
\% \text { EXCESS TOTAL AIR } \\
\% \text { OVERFIRE TOTAL AIR }\end{array}$ & $\begin{array}{l}42 \\
89 \\
25\end{array}$ & $\begin{array}{r}107 \\
178 \\
26\end{array}$ & $\begin{array}{r}93 \\
180 \\
31\end{array}$ & $\begin{array}{r}51 \\
110 \\
28\end{array}$ & $\begin{array}{l}33 \\
96 \\
32\end{array}$ \\
\hline $\begin{array}{l}\text { AVERAGE FLUE GAS (dry) } \\
\mathrm{CO}_{2}(\%) \\
\mathrm{O}_{2}(\%)-A C T U A L \\
\mathrm{CO} \text { (PPM) } \\
\mathrm{SO}_{2} \text { (PPM) } \\
\mathrm{NO}_{x} \text { (PPM) } \\
\mathrm{THC}(\mathrm{PPM})\end{array}$ & $\begin{array}{r}9.7 \\
9.5 \\
149 \\
422 \\
246 \\
2.0\end{array}$ & $\begin{array}{r}7.9 \\
12.5 \\
1002 \\
41 \\
49 \\
36\end{array}$ & $\begin{array}{r}6.6 \\
14.1 \\
704 \\
20 \\
37 \\
13\end{array}$ & $\begin{array}{r}9.2 \\
10.8 \\
147 \\
397 \\
207 \\
2.2\end{array}$ & $\begin{array}{r}10.7 \\
9.0 \\
190 \\
240 \\
140 \\
1.3\end{array}$ \\
\hline $\begin{array}{l}\text { AVERAGE FLUE GAS (dry) } \\
\mathrm{CO}_{2}(\%) \\
\mathrm{O}_{2}(\%)-\text { CORRECT TO } 0 \% \\
\mathrm{CO} \text { (PPM) } \\
\mathrm{SO}_{2} \text { (PPM) } \\
\mathrm{NO}_{x} \text { (PPM) } \\
\mathrm{THC}(\mathrm{PPM})\end{array}$ & $\begin{array}{r}17.7 \\
0.0 \\
273 \\
773 \\
451 \\
3.6\end{array}$ & $\begin{array}{r}19.5 \\
0.0 \\
2470 \\
102 \\
120 \\
90\end{array}$ & $\begin{array}{r}19.9 \\
0.0 \\
2129 \\
59 \\
111 \\
39\end{array}$ & $\begin{array}{r}18.9 \\
0.0 \\
303 \\
818 \\
426 \\
4.5\end{array}$ & $\begin{array}{r}18.8 \\
0.0 \\
334 \\
424 \\
245 \\
2.2\end{array}$ \\
\hline $\begin{array}{l}\text { LB/MMBTU (FUEL) } \\
\mathrm{CO} \\
\mathrm{SO}_{2} \\
\mathrm{NO}_{x} \text { as } \mathrm{NO}_{2} \\
\mathrm{THC}\end{array}$ & $\begin{array}{l}0.21 \\
1.35 \\
0.55 \\
0.0018\end{array}$ & $\begin{array}{l}1.63 \\
0.24 \\
0.19 \\
0.031\end{array}$ & $\begin{array}{l}1.58 \\
0.088 \\
0.11 \\
0.0157\end{array}$ & $\begin{array}{l}0.26 \\
1.32 \\
0.54 \\
0.0022\end{array}$ & $\begin{array}{l}0.33 \\
0.75 \\
0.33 \\
0.0017\end{array}$ \\
\hline CARBON CONVERSION (est \%) & 97 & 94 & 98 & 95 & 98 \\
\hline FLYASH (GR/SCF) & 0.014 & 0.007 & 0.034 & 0.026 & 0.044 \\
\hline
\end{tabular}

